Review

\title{
Profiling of LINE-1-Related Genes in Hepatocellular Carcinoma
}

\author{
Tomoyuki Honda ${ }^{1, *}$ and Md. Arifur Rahman ${ }^{1,2}$ \\ 1 Division of Virology, Department of Microbiology and Immunology, Osaka University Graduate School of \\ Medicine, Osaka 565-0871, Japan; arifur@nstu.edu.bd \\ 2 Department of Microbiology, Noakhali Science and Technology University, Noakhali 3814, Bangladesh \\ * Correspondence: thonda@virus.med.osaka-u.ac.jp; Tel.: +81-6-6879-3783
}

Received: 31 December 2018; Accepted: 29 January 2019; Published: 2 February 2019

check for updates

\begin{abstract}
Hepatocellular carcinoma (HCC) is a prime public health concern that accounts for most of the primary liver malignancies in humans. The most common etiological factor of HCC is hepatitis B virus (HBV). Despite recent advances in treatment strategies, there has been little success in improving the survival of HCC patients. To develop a novel therapeutic approach, evaluation of a working hypothesis based on different viewpoints might be important. Long interspersed element 1 (L1) retrotransposons have been suggested to play a role in HCC. However, the molecular machineries that can modulate L1 biology in HBV-related HCC have not been well-evaluated. Here, we summarize the profiles of expression and/or activation status of L1-related genes in HBV-related HCC, and HBVand HCC-related genes that may impact L1-mediated tumorigenesis. L1 restriction factors appear to be suppressed by HBV infection. Since some of the L1 restriction factors also limit HBV, these factors may be exhausted in HBV-infected cells, which causes de-suppression of L1. Several HBV- and HCC-related genes that interact with L1 can affect oncogenic processes. Thus, L1 may be a novel prime therapeutic target for HBV-related HCC. Studies in this area will provide insights into HCC and other types of cancers.
\end{abstract}

Keywords: hepatocellular carcinoma; hepatitis B virus; tumorigenesis; LINE-1; DNA damage; retrotransposition

\section{Introduction}

Hepatocellular carcinoma (HCC) is a prime public health concern that causes almost $90 \%$ of the primary liver malignancies in humans. HCC is the sixth most common cancer and is the fifth leading cancer in males and ninth most common cancer in females [1,2]. The mean 5-year survival rate of HCC patients was found to be between $25 \%$ to $60 \%$ [3]. Despite recent advances in treatment strategies, there has been little success in improving the survival of HCC patients.

The most common etiological factor of HCC is hepatitis B virus (HBV) infection [4]. Worldwide, over $50 \%$ of HBV patients with chronic HBV infections progress to liver cirrhosis (LC) and $70 \%$ to $90 \%$ of them eventually develop HCC $[5,6]$. At present, there are approximately 257 million HBV carriers, and 887,000 deaths were reported due to the HBV-related complications including LC and HCC in 2015 [7]. During HBV infection, the HBV partially double-stranded DNA genome (relaxed circular DNA, rcDNA) is repaired and converted into covalently closed circular DNA (cccDNA) that can act as a template for the synthesis of viral transcripts including pre-genomic RNA (pgRNA) [8-11]. pgRNA is reverse-transcribed to generate rcDNA for viral replication [10]. The HBV genome encodes at least four genes, pre-core / $\mathrm{HBc}, \mathrm{Pol}, \mathrm{HBs}$ and $\mathrm{HBx}$ [10,12]. Hepatitis B e antigen (HBeAg) and hepatitis B surface antigen (HBsAg) are $\mathrm{HBV}$-specific antigens derived from pre-core/ $\mathrm{HBc}$ and $\mathrm{HBs}$, respectively. 
The incidence of HCC or HBV persistent infections may vary with geography, race, age, and sex. Co-infection with hepatitis $\mathrm{C}$ virus $(\mathrm{HCV})$, a family history of $\mathrm{HCC}$, alcohol intake, $\mathrm{HBV}$ genotype $\mathrm{C}$, and core promoter mutations are considered to be risk factors for HCC [13-19]. For example, there is an increased risk of developing HCC in adult males and chronic hepatitis B patients with cirrhosis who contracted HBV in early childhood [3]. Patients who are both HBsAg- and HBeAg-positive have a 6-fold risk of developing HCC than those who are only HBsAg-positive [20]. However, the molecular mechanisms of how HBV contributes to HCC tumorigenesis are not fully understood.

Long interspersed element 1 (LINE-1 or L1) is a non-long terminal repeat (LTR) retrotransposon that comprises $\sim 17 \%$ of the human genome [21]. L1 can retrotranspose to new genomic loci in a "copy-and-paste" manner [22,23]. Most L1s are truncated and therefore defective for retrotransposition activity, whereas $~ 100$ copies remain competent [22,23]. Therefore, active retrotransposition of L1 can be a major source of endogenous mutagenesis in humans, which may contribute to genomic instability and tumorigenesis [24,25]. Consistently, L1 upregulation in cancer has been frequently reported [26-29]. In addition, L1 de novo insertions can alter gene expression [30,31], which also potentially contributes to cancer development [32-34]. Among cancers, HCC is considered to be the one in which L1 might be involved for the following reasons [31,32,34]. Firstly, the majority of L1 de novo insertions have been detected in cancers [35]. Secondly, HCC is an extraordinarily heterogenous cancer, apparently because of genomic instability [36,37]. Thirdly, endogenous L1 retrotransposition has been demonstrated to activate oncogenic pathways in HCC [31]. Fourthly, several L1 chimeric transcripts with host or viral genes are found in hepatitis virus-related HCC [38]. Finally, it has been demonstrated that L1 retorotransposition is a common feature of HCC caused by various mechanisms [34]. Based on these, we have speculated that HBV may modify L1 biology and thereby potentiate HBV-infected hepatocytes to develop HCC [32,33].

In this regard, we discuss the potential molecular linkages between HCC, especially HBV-related HCC, and L1. Starting with a brief introduction of the biology of L1 retrotransposon, we review the expression profile of L1-related genes in HCC and/or their roles in HBV-related HCC. Then, we illustrate the possible interactions between HBV- and HCC-related genes and L1. An understanding of the possible molecular links between HCC and L1 might open up avenues for the development of novel therapeutic approaches for this disease.

\section{Long Interspersed Element 1 (L1)}

Approximately half of the human genome consists of retrotransposons with or without LTRs. Among these, L1 is a unique non-LTR retrotransposon, because some of them are still capable of mobilization in the human genome [22,23]. L1s contain a $5^{\prime}$ untranslated region (UTR), two open reading frames (ORFs) that encode two proteins, ORF1p and ORF2p, and a $3^{\prime}$ UTR with a polyadenylation signal. ORF1p is an RNA-binding protein with nucleic acid chaperone activity, which is required for L1 retrotransposition [39]. ORF2p is responsible for endonuclease and reverse transcriptase activity [22,23]. L1 reverse-transcribes and integrates into new genomic loci by target-primed reverse transcription (TPRT) [40]. During TPRT, L1 creates a nicked DNA strand, which serves as a primer for reverse transcription, using the endonuclease activity of ORF2p. Environmental factors, such as chemicals, oxidative stress and infection, are capable of affecting L1 retrotransposition [32,41-43]. For example, human immunodeficiency virus type 1 (HIV-1) infection enhances L1 retrotransposition and increases the amount of L1 DNA [44]. HIV-1 Vpr and Vif proteins play a role in activation of L1 retrotransposition [44,45]. Therefore, it is reasonable to speculate that HBV may activate L1 retrotransposition.

Active L1 retrotransposition can potentiate oncogenic processes in various ways. As mentioned above, since L1 causes insertional mutations, any potential disruption of tumor suppressor genes by L1 retrotransposition could contribute to the development of tumors. L1 de novo insertions can affect the expression of nearby genes and the genes into which they have inserted [30,31]. If an L1 insertion occurs close to an oncogene or a tumor suppressor gene, the inserted L1 may increase 
oncogene expression or decrease the expression of tumor suppressor genes, thereby supporting tumor development. L1 provides preferential sites for genomic rearrangements [46], which may contribute to genomic instability that causes tumorigenesis. DNA strand-breaks produced by ORF2p during TPRT can also cause genomic instability. Occasionally, L1 retrotransposition creates new chimeric transcripts, which might also enhance tumor development [38].

\section{L1-Related Genes in Hepatocellular Carcinoma (HCC)}

Many host genes are involved in L1 biology. Among them, we focus on two categories of genes, i.e., genes related to host defense and DNA damage responses (DDRs), which may potentially affect the oncogenic processes of HCC (Figure 1). In addition, we summarize L1 de novo insertions that may involve HCC development.

A
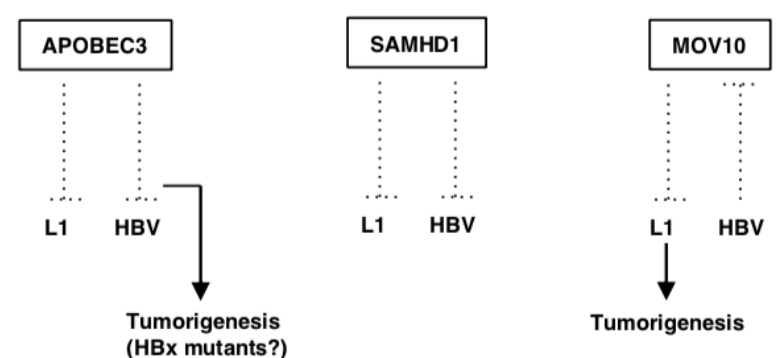

B
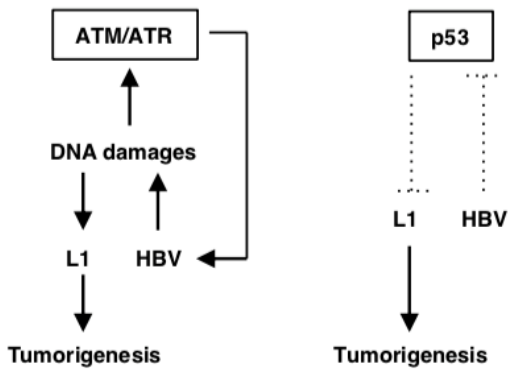

Figure 1. L1-related genes in HBV-related HCC. (A) Host defense genes against L1. APOBEC3s suppress L1 retrotransposition and HBV replication. Some APOBEC3s generate HBx mutants that cause gain of function, enhancing its oncogenic properties. SAMHD1 also inhibits both L1 retrotransposition and HBV replication. MOV10 is downregulated by HBV infection, which may upregulate L1 retrotransposition and accelerate tumorigenesis. (B) L1-related DDR genes. HBV appears to induce DNA damages, which can activate the ATM/ATR pathway, required for efficient HBV replication. On the other hand, HBV-induced DNA damages can potentiate L1 retrotransposition and cause genomic instability. HBV inactivates p53, which can activate L1 retrotransposition.

\subsection{Host Defense Genes Against L1}

Apolipoprotein B mRNA editing enzyme catalytic polypeptide 3 (APOBEC3), sterile alpha motif domain and HD domain-containing protein 1 (SAMHD1), and Moloney leukemia virus 10 homolog (MOV10) are three well-known genes that have been identified as host defense factors against HIV-1 and L1 [47-53]. Because HBV genome replications involve a reverse transcription step, similar to L1 or HIV-1, these factors also restrict HBV and might affect HBV-mediated tumorigenesis.

APOBEC3, a cytidine deaminase, whose family members inhibit L1 retrotransposition [51] reportedly hyper-edits the HBV DNA as well as inhibits HBV replication in vitro and in vivo [54-57]. APOBEC3s are incorporated into nascent HBV capsids, where they convert cytidine bases to uracil in newly synthesized DNA. This modification causes degradation of the modified HBV DNA or disruption of coding sequences by incorporating numerous G-to-A nucleotide mutations into the 
positive-strand of the viral DNA [54]. Thus, HBV could enhance L1 retrotransposition by competing with A3G restriction (Figure 1A). The APOBEC3B expression was up-regulated in a variety of cancers including HCC [58]. Furthermore, APOBEC3s play a role in the development of HCC during chronic HBV infection [54]. For example, some APOBEC3s generate HBx mutants that (especially the C-terminally truncated mutants) cause a gain of function, enhancing the colony forming ability and proliferative capacity of HBV-infected cells. As a result, the cells obtain a selective clonal growth advantage (Figure 1A) [59].

SAMHD1 restricts efficient viral cDNA synthesis by reducing the pool of dNTPs $[60,61]$. It can restrict DNA viruses and retroviruses including HIV-1 [62-66]. The depletion of cellular dNTP pools has been regarded as a key anti-viral mechanism of SAMHD1 [67]. Additionally, it also exhibits RNase activity that directly targets retroviral genomic RNA, blocking productive infection in a dNTPase-independent manner [68]. SAMHD1 also inhibits L1 retrotransposition by sequestrating the L1 ribonucleoprotein complex within stress granules [51] or suppressing L1 reverse-transcription (Figure 1A) [69]. In the HBV life cycle, SAMHD1 has no effect on covalently closed circular DNA (cccDNA) production or HBV gene expression, while it specifically inhibits the reverse-transcription step through the depletion of cellular dNTPs (Figure 1A) [70]. The full-length SAMHD1 acts as an anti-tumor factor by increasing the cell sensitivity to chemotherapy drugs [61]. Incorporation of exon-4 of SAMHD1 has been linked to a higher prevalence of HBV- and HCV-related HCC, which leads to an abnormal SAMHD1 translation termination that weakens the anti-tumor activity of SAMHD1 [61,71]. Although exon-4 incorporation might be an indicator of hepatocarcinogenesis, the precise mechanism behind the occurrence of this insertion still needs to be studied.

MOV10, an interferon (IFN)-inducible RNA helicase, has very broad and potent anti-retroviral activity [52,72,73], which also suppresses L1 retrotransposition (Figure 1A) [53]. The overexpression of exogenous MOV10 resulted in an increase of HBsAg, HBeAg and HBV mRNA levels at a low dose, and a decrease at a high dose, while HBV DNA was unaffected. By contrast, knockdown of MOV10 could suppress levels of HBsAg, HBeAg and HBV mRNA, while it had no effect on HBV DNA [74]. These results suggest that an appropriate level of exogenous MOV10 supported HBV replication [74]. Patients with chronic hepatitis B produced lower levels of MOV10 mRNA compared with healthy individuals [75]. Taken together, HBV may suppress the MOV10 expression, thereby enhancing L1 retrotransposition in infected hepatocytes (Figure 1A).

\subsection{L1-Related DDR Genes}

Ataxia telangiectasia mutated (ATM) and ATM-Rad3-related (ATR) are kinases activated by various types of DNA damages [76,77]. Activated ATM and ATR subsequently phosphorylate downstream substrates, Chk2 and Chk1, respectively, and p53. These effectors induce cell cycle arrest, DNA repair and/or cell apoptosis [76,77]. L1 retrotransposition is increased in ATM-deficient cells [78]. HBx activates the ATM-Chk2 pathway by inducing DNA damages [79]. Additionally, HBV infection triggers ATR-dependent DDRs and increases ATR and Chk1 phosphorylation levels [80]. Although the precise role of ATM and ATR in HBV replication is unclear, ATM-ATR kinase inhibitors suppressed HBV infection and replication (Figure 1B) [80]. Since L1 can retrotranspose into DNA damage sites in its endonuclease-independent manner [81], L1 retrotransposition may be enhanced by HBV-induced DNA damages (Figure 1B).

p53 is known to be a tumor suppressor protein encoded by the TP53 gene, which is closely associated with HCC through regulation of cell differentiation, cell cycle and cell apoptosis [82,83]. p53 activation is crucial for DDRs, effective chemosensitivity and improvement of the HCC prognosis [84]. p53 has been demonstrated to limit L1 retrotransposition, through which p53 might restrict oncogenesis, at least in part (Figure 1B) [85]. TP53 is mutated in more than $45 \%$ of HBV-related HCC and in $13 \%$ of HCV-related HCC [86]. Preferential mutation sites are located within the DNA-binding domain of p53, which reduces its binding affinity to responsive elements and therefore decreases expression of p53 target genes [87]. Although the molecular pathogenesis of HCC can involve the 
inactivation of the TP53 gene $[88,89]$, the absence of a TP53 somatic mutation in the majority of HCC cases [90] suggests that the inactivation can be achieved by other mechanism(s), such as p14 ARF inactivation [91] or the amplification/overexpression of its specific inhibitors, MDM2 and MDM4 [92]. In the HBV infection context, HBx binds to p53, inactivating p53 transactivation, which may contribute to hepatocarcinogenesis (Figure 1B) [93-95].

\subsection{L1 de novo Insertions}

As described in Section 2, L1 de novo insertions can trigger oncogenic processes. L1 de novo insertions into or nearby tumor suppressor genes or oncogenes may affect gene expression, thereby promoting tumorigenesis. L1 de novo insertions are categorized into two types, i.e., germline and somatic insertions. Germline L1 insertions are generated by retrotransposition events in germline cells, which will contribute to all tissues of the individual. An example of germline L1 insertions contributing to tumorigenesis is those into the mutated in colorectal cancer (MCC) gene that are associated with downregulation of the MCC gene [31]. MCC is a gene that suppresses the oncogenic Wnt/ $\beta$-catenin signaling pathway, which is frequently activated in HCC [96], suggesting that downregulation of MCC caused by L1 insertions can lead to oncogenesis.

L1 retrotransposition is usually suppressed in somatic cells. However, if somatic L1 retrotransposition happens, the insertion can fuel tumorigenesis. For example, a tumor-specific L1 somatic insertion is found at the transcriptional repressor suppression of tumorigenicity 18 (ST18) gene, a candidate oncogene in the liver, and the insertion activates ST18 expression [31]. Because the expression of ST18 is upregulated in several liver cancer cells and in tumors in a mouse-model for inflammation-driven HCC, and L1 insertion upregulates the expression of ST18 [31], L1 can enhance tumorigenesis through the upregulation of ST18 by an L1 de novo insertion to the ST18 locus.

\section{HBV- and HCC-Related Genes in L1 Biology}

Many studies have reported hypomethylation of L1 loci in HCC and HBV infections [97-100]. L1 hypomethylation has also been linked to poor outcomes of HCC [97,98]. Recently, L1 activation was shown to be a common feature of hepatocarcinogenesis [34]. In this section, we discuss the links between particular HBV- and HCC-related genes and L1, HBV insertions and L1, and the roles of an HBV-L1 chimeric transcript (Figure 2).
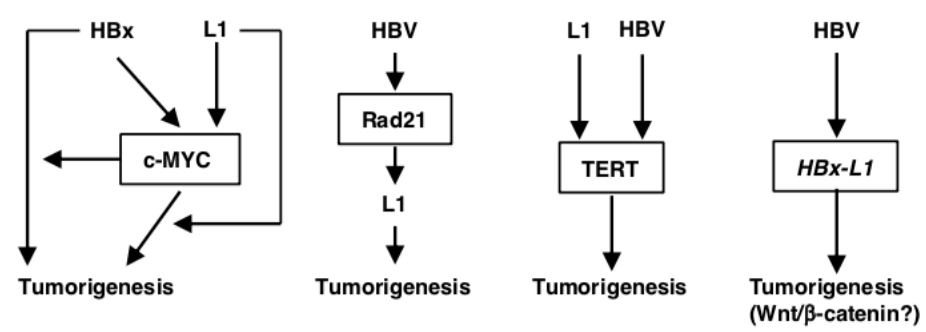

Figure 2. HBV- and HCC-related genes in L1 biology. HBx activates c-MYC, and HBx and c-MYC synergistically promote tumorigenesis. L1 de novo insertions were preferentially localized near the $c-M Y C$ gene, which may upregulate gene expression. L1 plays a role in genomic rearrangement in MYC-induced oncogenesis. Rad21 is upregulated in HBV-related HCC, which drives L1 expression. Upregulation of L1 may enhance L1 retrotransposition and thereby cancer development. HBV and L1 sequences are reportedly inserted into the TERT gene locus. The insertions upregulate the gene expression, which can affect tumorigenesis. The $H B x$ sequence is inserted into L1 loci, which generates $H B x-L 1$ chimeric transcripts. $H B x$-L1 functions as a non-coding RNA that activates the oncogenic $\mathrm{Wnt} / \beta$-catenin pathway.

\subsection{Myc}

A comprehensive review of all articles related to "HBV and HCC" published between 1973 and March 2018 has revealed that over 1300 host genes interact with at least one of the HBV proteins, 
the most frequent of which is HBx [101]. Of these, GPT, AFP, ALB, IFNA1, TP53 and MYC have been discussed in at least 50 different articles regarding HBV-related HCC [101]. Among these 6 genes, TP53 and MYC are oncogenes and L1 may play roles in TP53- and MYC-related oncogenesis. TP53 is frequently mutated in HBV-related HCC, whose mutation/inactivation has been associated with a poor outcome of HCC, as described above (Figure 1B) [86,88,89]. c-MYC is a critical target gene that is often activated by HBx, which in turn accelerates the oncogenic properties of HBx [102,103]. In a transgenic mouse model, $\mathrm{HBx}$ alone has no direct pathological effects on developing HCC. The c-MYC/HBx-expressing transgenic mice rapidly produce tumors compared with c-MYC-expressing transgenic mice, illustrating that the synergistic effect of HBx and c-MYC accelerates the development of liver cancer. Moreover, the interaction between HBx and c-MYC stabilizes c-MYC by inhibiting c-MYC ubiquitination, which ultimately contributes to viral oncogenesis (Figure 2) [104]. Because c-MYC regulates a number of cellular genes that are involved in HBV-related HCC, c-MYC is not only an oncogene but also modulates the oncogenic activity in HBV-mediated HCC [105]. L1 reportedly participates in genomic rearrangement in MYC-induced lymphoma, supporting the idea that L1 also contributes to MYC-mediated oncogenesis (Figure 2) [106]. Furthermore, L1 de novo insertions were preferentially localized near the $c-M Y C$ gene [107], which may upregulate gene expression and contribute to oncogenesis (Figure 2).

\subsection{CBX1, Rad21 and CENPA}

Several gene expression profiling studies of HCC are reported previously. We reviewed them and found only four articles that provided full lists of genes that were differentially expressed in HCC [108-111]. Huang et al. applied RNA-seq technology to identify genes dysregulated in HBV-related HCC patients [108]. In the study, 1378 differentially expressed genes were reported, among which 808 was upregulated and 570 was downregulated [108]. Boyault et al. analyzed the gene expression profile of HBV-related HCC patients by genome-wide transcriptome microarray and identified 471 upregulated and 167 downregulated genes [109]. Gopal et al. carried out integrative transcriptome analysis of HCC patients, where 459 and 332 genes were shown to be upregulated and downregulated, respectively [110]. Okabe et al. analyzed genome-wide gene expression by microarray, and found that 165 were upregulated while 170 genes were downregulated [111]. We found 28 upregulated and 11 downregulated genes common in three of four studies. Among them, $C B X 1$, Rad21 and CENPA are supposedly involved in L1 biology.

The Chromobox 1 (CBX1) gene encodes a Chromobox protein homolog 1 protein, also known as HP1, which recognizes and binds histone $\mathrm{H} 3$ tails methylated at Lys-9, altering the chromatin structure and usually leading to epigenetic repression [112,113]. Additionally, $C B X 1$ can function as an oncogene [114]. The expression of CBX1 noticeably increased in HCC tissues compared with the non-tumorous ones [114]. High CBX1 expression was significantly associated with larger tumor size, poor tumor differentiation and tumor vascular invasion [114]. CBX1 overexpression promoted cell proliferation and migration, while the CBX1 knockdown showed the opposite phenotypes. CBX1 was proposed to be preferentially recruited to LINE sequences to form heterochromatin [115]. Thus, CBX1 appears to be a negative regulator of L1, whose contribution to HBV-related HCC is unclear.

Rad21 is a subunit of the cohesion complex [116]. Dysregulated expression of Rad21 is common in epithelial cancers $[117,118]$ and its upregulation is associated with a poor prognosis [119]. Rad21 is reported to be enriched in the L1 promoter region and to drive L1 expression in human colorectal cancer [120]. Similarly, HBV may upregulate Rad21, which drives L1 expression and promotes L1 retrotransposition, resulting in the development of HCC (Figure 2) [120].

Centromere Protein A (CENPA) is a critical centromere-specific histone $\mathrm{H} 3$ variant that defines the neocentromeric chromatins [121]. Neocentromeres are ectopic centromeres that are able to assemble a functional kinetochore [122]. LINE-1 RNA is proposed to serve as an epigenetic determinant in neocentromere formation [123]. Because neocentromeres were detected in at least two types of human cancer and aberrant hypomethylation, which causes L1 upregulation, contributes to 
hepatocarcinogenesis, upregulation of CENPA and LINE-1 synergistically triggers neocentromere formation, which may support chromosome segregation during the oncogenic proliferation of HBV-infected hepatocytes.

\subsection{HBV Insertions}

A key event in chronic HBV infection is the integration of the HBV sequences into the host genome and a total of 5331 integration events have been reported [101]. There is a direct relationship between the HBV DNA integration and HCC progression [101]. The most frequently integrated viral genes are $H B C$ and $H B x$, while the most commonly reported integrated sites for HBV are the loci of the TERT, MLL4, FN1, CCNE1 and CCNA2 genes [101]. Except FN1, these integrations lead to the overexpression of the genes that have been implicated in HCC tumorigenesis [101].

The telomerase reverse transcriptase (TERT) gene is one of the most common genes associated with L1 de novo insertion [38,124]. In more than $90 \%$ of human malignancies including HCC, the TERT gene is reported to be activated by TERT amplification or TERT promoter mutations [125-127], leading to infinite proliferation of the cells [125]. TERT promoter mutations are thought to be a new biomarker to predict HCC as they are frequently found in premalignant lesions [128] and at an early stage of tumorigenesis, such as stage I HCCs [129]. Since aberrant expression of TERT is associated with tumor development, HBV and/or L1 sequence insertions in the proximity of the TERT locus may have a role in carcinogenesis by affecting the TERT expression (Figure 2) [125]. Consistently, the highest frequency of HBV integration is detected in the TERT gene, causing expression or reactivation of the TERT gene [130-133].

\subsection{The HBx-L1 Chimeric Transcript}

$\mathrm{HBV}$ integration into the intergenic region is also very common. Among the 9249 articles reviewed by Lee et al., 2789 were found to be integrated in intergenic regions [101]. Of these, 92 mapped to repeat sequences, of which 36 were on LINEs and 28 were in the L1 sub-family [101]. HBx-L1, a chimeric transcript of the $H B x$ and $L 1$ sequences found in HBV-related HCC, was reportedly detected in more than $20 \%$ of HBV-related HCC and correlates with a poor outcome of HCC (Figure 2) [38]. HBx-L1 knockdown reduces the migratory and invasive properties of HBV-positive HCC cells. $H B x-L 1$ overexpression confers growth advantage and promotes cell migration and invasion. The chimeric protein-coding potential of $H B x-L 1$ is not required for these effects, suggesting that $H B x$-L1 may function as a long non-coding RNA that promotes HCC phenotypes. The expression of the $H B x-L 1$ chimeric transcript reduces the level of microRNA-122 (miR-122), increasing the activity of the Wnt/ $\beta$-catenin signaling and inducing colony formation and cell cycle progression (Figure 2) $[38,132,134,135]$.

\section{Conclusions}

In HBV-related HCC, the expression and/or activation status of L1-related genes is altered, which may contribute to L1 activation and HCC tumorigenesis. To investigate this hypothesis, it is important to evaluate the L1 activation status in each cancer cell and surrounding non-cancer cells because HCC is highly heterogenous and L1 activity in each cell might be different [35-37]. Several antibodies against L1 (e.g., JH73 and AH40.1) have been established previously [136-138]. In addition, we have successfully generated a novel antibody against ORF1p (\#18469) (Figure 3). These L1-specific antibodies might be a helpful tool for immunohistological analysis of HCC samples. Recently, ORF1p was shown to enhance the transcription factor activity of pregnenolone $\mathrm{X}$ receptor and to be involved in sorafenib-resistance in HCC cells [139]. The involvement of ORF1p in drug resistance in HCC further emphasizes the importance of evaluation of the ORF1p expression. 
A

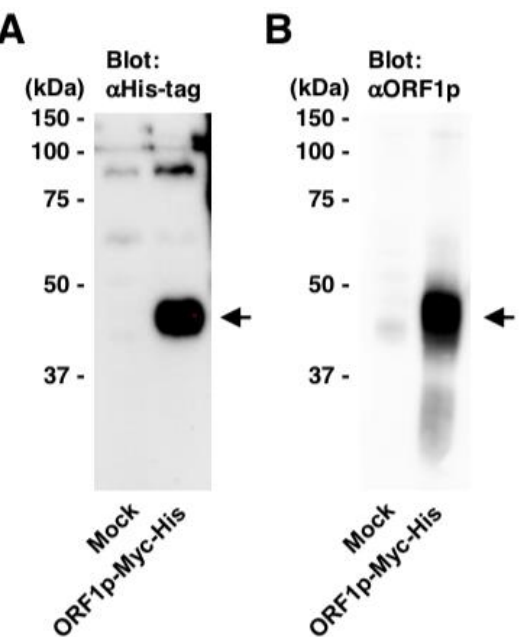

Figure 3. Generation of an antibody against L1 ORF1p. A rabbit antibody against L1 ORF1p (\#18469) was generated using a synthetic ORF1p peptide [27-45 aa]. The homogenate of the cells transfected with pEF-Myc-His (Invitrogen) or pEF-ORF1p-Myc-His was subjected to western blotting using anti-His-tag (A) and anti-ORF1p (\#18469) antibodies (B). Arrows, bands of ORF1p.

Although L1 is likely to be involved in the oncogenic processes of HBV-related HCC, it has not yet been demonstrated whether HBV indeed modulates L1 retrotransposition. HBV genes often contribute to the development of HCC. Among them, HBx is the best-studied viral protein in HBV-related HCC. $\mathrm{HBx}$ associates with various host factors in multiple cancer-related biological pathways. Therefore, HBx may be a candidate that modulates L1 expression and/or retrotransposition, by which oncogenic processes are potentiated. At present, we cannot exclude the possibility that other HBV proteins contribute to the regulation of L1 activity. Further investigation will be required for clarifying this point. Intriguingly, we have demonstrated that another oncogenic virus, Kaposi's sarcoma-associated herpesvirus, can enhance L1 retrotransposition [140], which may highlight the importance of L1 in HBV-mediated oncogenesis.

Recently, we have also reported that capsaicin, a compound with anti-tumor activity, can suppress L1 retrotransposition [141]. This result suggests the possibility that some anti-tumor agents might exert their anti-tumor effect through the inhibition of L1 retrotransposition. Given that L1 plays important roles in HBV-related HCC tumorigenesis, L1 may be a novel prime therapeutic target for HBV-related HCC. Research in this regard will provide insights into HCC and other types of tumors.

Author Contributions: T.H. and M.A.R. wrote the paper.

Funding: This study was supported in part by JSPS KAKENHI Grant Numbers 15K08496, 18H02664 and 18K19449, the Program on the Innovative Development and the Application of New Drugs for Hepatitis B from Japan Agency for Medical Research and Development (AMED), and grants from the Takeda Science Foundation, Kobayashi International Scholarship Foundation, The Shimizu Foundation for Immunology and Neuroscience Grant for 2015 and Akaeda Medical Research Foundation (T.H.).

Conflicts of Interest: The authors declare no conflicts of interest.

\section{References}

1. Ferenci, P.; Fried, M.; Labrecque, D.; Bruix, J.; Sherman, M.; Omata, M.; Heathcote, J.; Piratsivuth, T.; Kew, M.; Otegbayo, J.A.; et al. Hepatocellular Carcinoma (HCC). J. Clin. Gastroenterol. 2010, 44, 239-245. [CrossRef] [PubMed]

2. Torre, L.A.; Siegel, R.L.; Ward, E.M.; Jemal, A. Global Cancer Incidence and Mortality Rates and Trends-An Update. Cancer Epidemiol. Biomark. Prev. 2016, 25, 16-27. [CrossRef] [PubMed]

3. Hollinger, F.B.; Liang, T.J. Hepatitis B Virus, 4th ed.; Fields Virology; Lippincott-Raven Publishers: Philadelphia, PA, USA, 2001. 
4. Ghouri, Y.A.; Mian, I.; Rowe, J.H. Review of hepatocellular carcinoma: Epidemiology, etiology, and carcinogenesis. J. Carcinog. 2017, 16, 1. [PubMed]

5. Ganem, D.; Prince, A.M. Hepatitis B Virus Infection-Natural History and Clinical Consequences. N. Engl. J. Med. 2004, 350, 1118-1129. [CrossRef] [PubMed]

6. Yang, J.D.; Kim, W.R.; Coelho, R.; Mettler, T.A.; Benson, J.T.; Sanderson, S.O.; Therneau, T.M.; Kim, B.; Roberts, L.R. Cirrhosis is Present in Most Patients With Hepatitis B and Hepatocellular Carcinoma. Clin. Gastroenterol. Hepatol. 2011, 9, 64-70. [CrossRef] [PubMed]

7. World Health Organization. Hepatitis B World Health Organization Fact Sheet. Available online: https: //www.who.int/news-room/fact-sheets/detail/hepatitis-b (accessed on 30 December 2018).

8. Li, X.; Zhao, J.; Yuan, Q.; Xia, N. Detection of HBV Covalently Closed Circular DNA. Viruses 2017, 9, 139. [CrossRef] [PubMed]

9. Summers, J.; O'Connell, A.; Millman, I. Genome of hepatitis B virus: Restriction enzyme cleavage and structure of DNA extracted from Dane particles. Proc. Natl. Acad. Sci. USA 1975, 72, 4597-4601. [CrossRef]

10. Beck, J.; Nassal, M. Hepatitis B virus replication. World J. Gastroenterol. 2007, 13, 48-64. [CrossRef]

11. Seeger, C.; Mason, W.S. Hepatitis B Virus Biology. Microbiol. Mol. Biol. Rev. 2000, 64, 51-68. [CrossRef]

12. Patient, R.; Hourioux, C.; Sizaret, P.Y.; Trassard, S.; Sureau, C.; Roingeard, P. Hepatitis B virus subviral envelope particle morphogenesis and intracellular trafficking. J. Virol. 2007, 81, 3842-3851. [CrossRef]

13. Tang, Z.Y. Hepatocellular carcinoma-cause, treatment and metastasis. World J. Gastroenterol. 2001, 7, 445-454. [CrossRef] [PubMed]

14. Benvegnù, L.; Gios, M.; Boccato, S.; Alberti, A. Natural history of compensated viral cirrhosis: A prospective study on the incidence and hierarchy of major complications. Gut 2004, 53, 744-749. [CrossRef] [PubMed]

15. Petersen, G.M. Familial Aggregation: Sorting Susceptibility From Shared Environment. J. Natl. Cancer Inst. 2000, 92, 1114-1115. [CrossRef] [PubMed]

16. Ohnishi, K.; Iida, S.; Iwama, S.; Goto, N.; Nomura, F.; Takashi, M.; Mishima, A.; Kono, K.; Kimura, K.; Musha, H.; et al. The Effect of Chronic Habitual Alcohol Intake on the Development of Liver Cirrhosis and Hepatocellular Carcinoma: Relation to Hepatitis B Surface Antigen Carriage. Am. Cancer Soc. 1981, 672-677. [CrossRef]

17. Bae, S.H.; Yoon, S.K.; Jang, J.W.; Kim, C.W.; Nam, S.W.; Choi, J.Y.; Kim, B.S.; Park, Y.M.; Suzuki, S.; Sugauchi, F.; et al. Hepatitis B virus genotype C prevails among chronic carriers of the virus in Korea. J. Korean Med. Sci. 2005, 20, 816-820. [CrossRef] [PubMed]

18. Yu, M.W.; Yeh, S.H.H.; Chen, P.J.J.; Liaw, Y.F.F.; Lin, C.L.L.; Liu, C.J.J.; Shih, W.L.L.; Kao, J.H.H.; Chen, D.S.S.; Chen, C.J.J. Hepatitis B Virus Genotype and DNA Level and Hepatocellular Carcinoma: A Prospective Study in Men. J. Natl. Cancer Inst. 2005, 97, 265-272. [CrossRef]

19. Kao, J.; Chen, P.; Lai, M.; Chen, D. Basal core promoter mutations of hepatitis B virus increase the risk of hepatocellular carcinoma in hepatitis B carriers. Gastroenterology 2003, 124, 327-334. [CrossRef]

20. Yang, H.I.; Lu, S.N.; Liaw, Y.F.; You, S.L.; Sun, C.A.; Wang, L.Y.; Hsiao, C.K.; Chen, P.J.; Chen, D.S.; Chen, C.J.; et al. Hepatitis B e Antigen and the Risk of Hepatocellular Carcinoma. N. Engl. J. Med. 2002, 347, 168-174. [CrossRef]

21. Lander, E.S.; Linton, L.M.; Birren, B.; Nusbaum, C.; Zody, M.C.; Baldwin, J.; Devon, K.; Dewar, K.; Doyle, M.; FitzHugh, W.; et al. Initial sequencing and analysis of the human genome. Nature 2001, 409, 860-921.

22. Beck, C.R.; Collier, P.; Macfarlane, C.; Malig, M.; Kidd, J.M.; Eichler, E.E.; Badge, R.M.; Moran, J.V. LINE-1 retrotransposition activity in human genomes. Cell 2010, 141, 1159-1170. [CrossRef]

23. Brouha, B.; Schustak, J.; Badge, R.M.; Lutz-Prigge, S.; Farley, A.H.; Moran, J.V.; Kazazian, H.H. Hot L1s account for the bulk of retrotransposition in the human population. Proc. Natl. Acad. Sci. USA 2003, 100, 5280-5285. [CrossRef] [PubMed]

24. Burns, K.H.; Boeke, J.D. Human Transposon Tectonics. Cell 2012, 149, 740-752. [CrossRef] [PubMed]

25. Levin, H.L.; Moran, J.V. Dynamic interactions between transposable elements and their hosts. Nat. Rev. Genet. 2011, 12, 615-627. [CrossRef] [PubMed]

26. Rodić, N.; Sharma, R.; Sharma, R.; Zampella, J.; Dai, L.; Taylor, M.S.; Hruban, R.H.; Iacobuzio-Donahue, C.A.; Maitra, A.; Torbenson, M.S.; et al. Long Interspersed Element-1 Protein Expression Is a Hallmark of Many Human Cancers. Am. J. Pathol. 2014, 184, 1280-1286. [CrossRef] [PubMed] 
27. Rangasamy, D.; Lenka, N.; Ohms, S.; Dahlstrom, J.E.; Blackburn, A.C.; Board, P.G. Activation of LINE-1 Retrotransposon Increases the Risk of Epithelial-Mesenchymal Transition and Metastasis in Epithelial Cancer. Curr. Mol. Med. 2015, 15, 588-597. [PubMed]

28. Kemp, J.R.; Longworth, M.S. Crossing the LINE Toward Genomic Instability: LINE-1 Retrotransposition in Cancer. Front. Chem. 2015, 3, 68. [CrossRef] [PubMed]

29. Briggs, E.M.; Ha, S.; Mita, P.; Brittingham, G.; Sciamanna, I.; Spadafora, C.; Logan, S.K. Long interspersed nuclear element-1 expression and retrotransposition in prostate cancer cells. Mob. DNA 2018, 9, 1. [CrossRef] [PubMed]

30. Lee, E.; Iskow, R.; Yang, L.; Gokcumen, O.; Haseley, P.; Luquette, L.J.; Lohr, J.G.; Harris, C.C.; Ding, L.; Wilson, R.K.; et al. Landscape of somatic retrotransposition in human cancers. Science 2012, 337, 967-971. [CrossRef] [PubMed]

31. Shukla, R.; Upton, K.R.; Muñoz-Lopez, M.; Gerhardt, D.J.; Fisher, M.E.; Nguyen, T.; Brennan, P.M.; Baillie, J.K.; Collino, A.; Ghisletti, S.; et al. Endogenous retrotransposition activates oncogenic pathways in hepatocellular carcinoma. Cell 2013, 153, 101-111. [CrossRef]

32. Honda, T. Links between Human LINE-1 Retrotransposons and Hepatitis Virus-Related Hepatocellular Carcinoma. Front. Chem. 2016, 4, 21. [CrossRef]

33. Honda, T. Potential Links between Hepadnavirus and Bornavirus Sequences in the Host Genome and Cancer. Front. Microbiol. 2017, 8, 2537. [CrossRef] [PubMed]

34. Schauer, S.N.; Carreira, P.E.; Shukla, R.; Gerhardt, D.J.; Gerdes, P.; Sanchez-Luque, F.J.; Nicoli, P.; Kindlova, M.; Ghisletti, S.; Dos Santos, A.; et al. L1 retrotransposition is a common feature of mammalian hepatocarcinogenesis. Genome Res. 2018, 28, 639-653. [CrossRef] [PubMed]

35. Goodier, J.L. Retrotransposition in tumors and brains. Mob. DNA 2014, 5, 11. [CrossRef] [PubMed]

36. Rao, C.V.; Asch, A.S.; Yamada, H.Y. Frequently mutated genes/pathways and genomic instability as prevention targets in liver cancer. Carcinogenesis 2017, 38, 2-11. [CrossRef] [PubMed]

37. Lin, D.C.C.; Mayakonda, A.; Dinh, H.Q.; Huang, P.; Lin, L.; Liu, X.; Ding, L.W.; Wang, J.; Berman, B.P.; Song, E.W.W.; et al. Genomic and Epigenomic Heterogeneity of Hepatocellular Carcinoma. Cancer Res. 2017, 77, 2255-2265. [CrossRef] [PubMed]

38. Lau, C.C.; Sun, T.; Ching, A.K.K.; He, M.; Li, J.W.; Wong, A.M.; Co, N.N.; Chan, A.W.H.; Li, P.S.; Lung, R.W.M.; et al. Viral-human chimeric transcript predisposes risk to liver cancer development and progression. Cancer Cell 2014, 25, 335-349. [CrossRef] [PubMed]

39. Khazina, E.; Truffault, V.; Büttner, R.; Schmidt, S.; Coles, M.; Weichenrieder, O. Trimeric structure and flexibility of the L1ORF1 protein in human L1 retrotransposition. Nat. Struct. Mol. Biol. 2011, 18, 1006-1014. [CrossRef]

40. Feng, Q.; Moran, J.V.; Kazazian, H.H.; Boeke, J.D. Human L1 Retrotransposon Encodes a Conserved Endonuclease Required for Retrotransposition. Cell 1996, 87, 905-916. [CrossRef]

41. Terasaki, N.; Goodier, J.L.; Cheung, L.E.; Wang, Y.J.; Kajikawa, M.; Kazazian, H.H.; Okada, N. In vitro screening for compounds that enhance human L1 mobilization. PLoS ONE 2013, 8, e74629. [CrossRef]

42. Giorgi, G.; Marcantonio, P.; Del Re, B. LINE-1 retrotransposition in human neuroblastoma cells is affected by oxidative stress. Cell Tissue Res. 2011, 346, 383-391. [CrossRef]

43. Bundo, M.; Toyoshima, M.; Okada, Y.; Akamatsu, W.; Ueda, J.; Nemoto-Miyauchi, T.; Sunaga, F.; Toritsuka, M.; Ikawa, D.; Kakita, A.; et al. Increased 11 retrotransposition in the neuronal genome in schizophrenia. Neuron 2014, 81, 306-313. [CrossRef] [PubMed]

44. Jones, R.B.; Song, H.; Xu, Y.; Garrison, K.E.; Buzdin, A.A.; Anwar, N.; Hunter, D.V.; Mujib, S.; Mihajlovic, V.; Martin, E.; et al. LINE-1 retrotransposable element DNA accumulates in HIV-1-infected cells. J. Virol. 2013, 87, 13307-13320. [CrossRef] [PubMed]

45. Iijima, K.; Okudaira, N.; Tamura, M.; Doi, A.; Saito, Y.; Shimura, M.; Goto, M.; Matsunaga, A.; Kawamura, Y.I.; Otsubo, T.; et al. Viral protein R of human immunodeficiency virus type-1 induces retrotransposition of long interspersed element-1. Retrovirology 2013, 10, 83. [CrossRef] [PubMed]

46. Burwinkel, B.; Kilimann, M.W. Unequal homologous recombination between LINE-1 elements as a mutational mechanism in human genetic disease. J. Mol. Biol. 1998, 277, 513-517. [CrossRef]

47. Mbisa, J.L.; Bu, W.; Pathak, V.K. APOBEC3F and APOBEC3G inhibit HIV-1 DNA integration by different mechanisms. J. Virol. 2010, 84, 5250-5259. [CrossRef] [PubMed] 
48. Nowarski, R.; Prabhu, P.; Kenig, E.; Smith, Y.; Britan-Rosich, E.; Kotler, M. APOBEC3G Inhibits HIV-1 RNA Elongation by Inactivating the Viral Trans-Activation Response Element. J. Mol. Biol. 2014, 426, 2840-2853. [CrossRef] [PubMed]

49. Kinomoto, M.; Kanno, T.; Shimura, M.; Ishizaka, Y.; Kojima, A.; Kurata, T.; Sata, T.; Tokunaga, K. All APOBEC3 family proteins differentially inhibit LINE-1 retrotransposition. Nucleic Acids Res. 2007, 35, 2955-2964. [CrossRef]

50. Antonucci, J.M.; St. Gelais, C.; Wu, L. The Dynamic Interplay between HIV-1, SAMHD1, and the Innate Antiviral Response. Front. Immunol. 2017, 8, 1541. [CrossRef]

51. Hu, S.; Li, J.; Xu, F.; Mei, S.; Le Duff, Y.; Yin, L.; Pang, X.; Cen, S.; Jin, Q.; Liang, C.; et al. SAMHD1 Inhibits LINE-1 Retrotransposition by Promoting Stress Granule Formation. PLoS Genet. 2015, 11, e1005367. [CrossRef]

52. Burdick, R.; Smith, J.L.; Chaipan, C.; Friew, Y.; Chen, J.; Venkatachari, N.J.; Delviks-Frankenberry, K.A.; Hu, W.-S.; Pathak, V.K. P Body-Associated Protein Mov10 Inhibits HIV-1 Replication at Multiple Stages. J. Virol. 2010, 84, 10241-10253. [CrossRef]

53. Li, X.; Zhang, J.; Jia, R.; Cheng, V.; Xu, X.; Qiao, W.; Guo, F.; Liang, C.; Cen, S. The MOV10 Helicase Inhibits LINE-1 Mobility. J. Biol. Chem. 2013, 288, 21148-21160. [CrossRef] [PubMed]

54. Janahi, E.M.; McGarvey, M.J. The inhibition of hepatitis B virus by APOBEC cytidine deaminases. J. Viral Hepat. 2013, 20, 821-828. [CrossRef] [PubMed]

55. Mohamadkhani, A.; Pourdadash, A.; Tayebi, S.; Estakhri, A.; Nazem, H.; Sotoudeh, M.; Poustchi, H. The potential role of APOBEC3G in limiting replication of hepatitis B virus. Arab J. Gastroenterol. 2012, 13, 170-173. [CrossRef] [PubMed]

56. Zhao, D.; Wang, X.; Lou, G.; Peng, G.; Li, J.; Zhu, H.; Chen, F.; Li, S.; Liu, D.; Chen, Z.; et al. APOBEC3G directly binds Hepatitis B virus core protein in cell and cell free systems. Virus Res. 2010, 151, 213-219. [CrossRef] [PubMed]

57. Turelli, P.; Mangeat, B.; Jost, S.; Vianin, S.; Trono, D. Inhibition of Hepatitis B Virus Replication by APOBEC3G. Science 2004, 303, 1829. [CrossRef] [PubMed]

58. Zou, J.; Wang, C.; Ma, X.; Wang, E.; Peng, G. APOBEC3B, a molecular driver of mutagenesis in human cancers. Cell Biosci. 2017, 7, 29. [CrossRef] [PubMed]

59. Xu, R.; Zhang, X.; Zhang, W.; Fang, Y.; Zheng, S.; Yu, X.F. Association of human APOBEC3 cytidine deaminases with the generation of hepatitis virus $\mathrm{B} x$ antigen mutants and hepatocellular carcinoma. Hepatology 2007, 46, 1810-1820. [CrossRef]

60. Chen, Z.; Zhu, M.; Pan, X.; Zhu, Y.; Yan, H.; Jiang, T.; Shen, Y.Y.; Dong, X.; Zheng, N.; Lu, J.; et al. Inhibition of Hepatitis B virus replication by SAMHD1. Biochem. Biophys. Res. Commun. 2014, 450, 1462-1468. [CrossRef]

61. Shi, Y.; Lv, G.; Chu, Z.; Piao, L.; Liu, X.; Wang, T.; Jiang, Y.; Zhang, P. Identification of natural splice variants of SAMHD1 in virus-infected HCC. Oncol. Rep. 2014, 31, 687-692. [CrossRef]

62. Chen, Z.; Zhang, L.; Ying, S. SAMHD1: A novel antiviral factor in intrinsic immunity. Future Microbiol. 2012, 7, 1117-1126. [CrossRef]

63. Hollenbaugh, J.A.; Gee, P.; Baker, J.; Daly, M.B.; Amie, S.M.; Tate, J.; Kasai, N.; Kanemura, Y.; Kim, D.H.; Ward, B.M.; et al. Host Factor SAMHD1 Restricts DNA Viruses in Non-Dividing Myeloid Cells. PLoS Pathog. 2013, 9, e1003481. [CrossRef] [PubMed]

64. Gramberg, T.; Kahle, T.; Bloch, N.; Wittmann, S.; Müllers, E.; Daddacha, W.; Hofmann, H.; Kim, B.; Lindemann, D.; Landau, N.R. Restriction of diverse retroviruses by SAMHD1. Retrovirology 2013, 10, 26. [CrossRef] [PubMed]

65. Goldstone, D.C.; Ennis-Adeniran, V.; Hedden, J.J.; Groom, H.C.T.; Rice, G.I.; Christodoulou, E.; Walker, P.A.; Kelly, G.; Haire, L.F.; Yap, M.W.; et al. HIV-1 restriction factor SAMHD1 is a deoxynucleoside triphosphate triphosphohydrolase. Nature 2011, 480, 379-382. [CrossRef] [PubMed]

66. Laguette, N.; Sobhian, B.; Casartelli, N.; Ringeard, M.; Chable-Bessia, C.; Ségéral, E.; Yatim, A.; Emiliani, S.; Schwartz, O.; Benkirane, M. SAMHD1 is the dendritic- and myeloid-cell-specific HIV-1 restriction factor counteracted by Vpx. Nature 2011, 474, 654-657. [CrossRef] [PubMed]

67. Lahouassa, H.; Daddacha, W.; Hofmann, H.; Ayinde, D.; Logue, E.C.; Dragin, L.; Bloch, N.; Maudet, C.; Bertrand, M.; Gramberg, T.; et al. SAMHD1 restricts the replication of human immunodeficiency virus type 1 by depleting the intracellular pool of deoxynucleoside triphosphates. Nat. Immunol. 2012, 13, 223-228. [CrossRef] [PubMed] 
68. Choi, J.; Ryoo, J.; Oh, C.; Hwang, S.; Ahn, K. SAMHD1 specifically restricts retroviruses through its RNase activity. Retrovirology 2015, 12, 46. [CrossRef] [PubMed]

69. Zhao, K.; Du, J.; Han, X.; Goodier, J.L.; Li, P.; Zhou, X.; Wei, W.; Evans, S.L.; Li, L.; Zhang, W.; et al. Modulation of LINE-1 and Alu/SVA retrotransposition by Aicardi-Goutières syndrome-related SAMHD1. Cell Rep. 2013, 4, 1108-1115. [CrossRef] [PubMed]

70. Jeong, G.U.; Park, I.H.; Ahn, K.; Ahn, B.Y. Inhibition of hepatitis B virus replication by a dNTPase-dependent function of the host restriction factor SAMHD1. Virology 2016, 495, 71-78. [CrossRef]

71. Welbourn, S.; Miyagi, E.; White, T.E.; Diaz-Griffero, F.; Strebel, K. Identification and characterization of naturally occurring splice variants of SAMHD1. Retrovirology 2012, 9, 86. [CrossRef]

72. Furtak, V.; Mulky, A.; Rawlings, S.A.; Kozhaya, L.; Lee, K.; KewalRamani, V.N.; Unutmaz, D. Perturbation of the P-Body Component Mov10 Inhibits HIV-1 Infectivity. PLoS ONE 2010, 5, e9081. [CrossRef]

73. Wang, X.; Han, Y.; Dang, Y.; Fu, W.; Zhou, T.; Ptak, R.G.; Zheng, Y.H. Moloney Leukemia Virus 10 (MOV10) Protein Inhibits Retrovirus Replication. J. Biol. Chem. 2010, 285, 14346-14355. [CrossRef]

74. Ma, Y.X.; Li, D.; Fu, L.J.; Fu, B.Q.; Chen, S.J.; Xu, W.Z.; Teng, X.; Song, Z.W.; Gu, H.X. The role of Moloney leukemia virus 10 in hepatitis B virus expression in hepatoma cells. Virus Res. 2015, 197, 85-91. [CrossRef] [PubMed]

75. Song, Z.W.; Ma, Y.X.; Fu, B.Q; Teng, X.; Chen, S.J.; Xu, W.Z.; Gu, H.X. Altered mRNA levels of MOV10, A3G, and IFN- $\alpha$ in patients with chronic hepatitis B. J. Microbiol. 2014, 52, 510-514. [CrossRef] [PubMed]

76. Ditch, S.; Paull, T.T. The ATM protein kinase and cellular redox signaling: Beyond the DNA damage response. Trends Biochem. Sci. 2012, 37, 15-22. [CrossRef] [PubMed]

77. Smith, J.; Tho, L.M.; Xu, N.; Gillespie, D.A. The ATM-Chk2 and ATR-Chk1 Pathways in DNA Damage Signaling and Cancer. Adv Cancer Res. 2010, 108, 73-112. [PubMed]

78. Coufal, N.G.; Garcia-Perez, J.L.; Peng, G.E.; Marchetto, M.C.N.; Muotri, A.R.; Mu, Y.; Carson, C.T.; Macia, A.; Moran, J.V.; Gage, F.H. Ataxia telangiectasia mutated (ATM) modulates long interspersed element-1 (L1) retrotransposition in human neural stem cells. Proc. Natl. Acad. Sci. USA 2011, 108, 20382-20387. [CrossRef] [PubMed]

79. Kim, S.; Lee, H.S.; Ji, J.H.; Cho, M.Y.; Yoo, Y.S.; Park, Y.Y.; Cha, H.J.; Lee, Y.; Kim, Y.; Cho, H. Hepatitis B virus $X$ protein activates the ATM-Chk2 pathway and delays cell cycle progression. J. Gen. Virol. 2015, 96, 2242-2251. [CrossRef]

80. Zhao, F.; Hou, N.B.; Song, T.; He, X.; Zheng, Z.R.; Ma, Q.J.; Li, L.; Zhang, Y.H.; Zhong, H. Cellular DNA repair cofactors affecting hepatitis B virus infection and replication. World J. Gastroenterol. 2008, 14, 5059-5065. [CrossRef]

81. Sen, S.K.; Huang, C.T.; Han, K.; Batzer, M.A. Endonuclease-independent insertion provides an alternative pathway for L1 retrotransposition in the human genome. Nucleic Acids Res. 2007, 35, 3741-3751. [CrossRef]

82. Dumble, M.L.; Croager, E.J.; Yeoh, G.C.T.; Quail, E.A. Generation and characterization of p53 null transformed hepatic progenitor cells: Oval cells give rise to hepatocellular carcinoma. Carcinogenesis 2002, 23, 435-445. [CrossRef]

83. Lechel, A.; Holstege, H.; Begus, Y.; Schienke, A.; Kamino, K.; Lehmann, U.; Kubicka, S.; Schirmacher, P.; Jonkers, J.; Rudolph, K.L. Telomerase Deletion Limits Progression of p53-Mutant Hepatocellular Carcinoma With Short Telomeres in Chronic Liver Disease. Gastroenterology 2007, 132, 1465-1475. [CrossRef] [PubMed]

84. Kunst, C.; Haderer, M.; Heckel, S.; Schlosser, S.; Müller, M. The p53 family in hepatocellular carcinoma. Transl. Cancer Res. 2016, 5, 632-638. [CrossRef]

85. Wylie, A.; Jones, A.E.; D’Brot, A.; Lu, W.J.; Kurtz, P.; Moran, J.V.; Rakheja, D.; Chen, K.S.; Hammer, R.E.; Comerford, S.A.; et al. p53 genes function to restrain mobile elements. Genes Dev. 2016, 30, 64-77. [CrossRef] [PubMed]

86. Shiraha, H.; Yamamoto, K.; Namba, M. Human hepatocyte carcinogenesis. Int. J. Oncol. 2013, 42, $1133-1138$. [CrossRef] [PubMed]

87. Meng, X.; Franklin, D.A.; Dong, J.; Zhang, Y. MDM2-p53 pathway in hepatocellular carcinoma. Cancer Res. 2014, 74, 7161-7167. [CrossRef]

88. Soini, Y.; Chia, S.C.; Bennett, W.P.; Groopman, J.D.; Wang, J.S.; DeBenedetti, V.M.; Cawley, H.; Welsh, J.A.; Hansen, C.; Bergasa, N.V.; et al. An aflatoxin-associated mutational hotspot at codon 249 in the p53 tumor suppressor gene occurs in hepatocellular carcinomas from Mexico. Carcinogenesis 1996, 17, 1007-1012. [CrossRef] 
89. Stähler, F.; Roemer, K. Mutant p53 can provoke apoptosis in p53-deficient Hep3B cells with delayed kinetics relative to wild-type p53. Oncogene 1998, 17, 3507-3512. [CrossRef]

90. Ueda, H.; Ullrich, S.J.; Gangemi, J.D.; Kappel, C.A.; Ngo, L.; Feitelson, M.A.; Jay, G. Functional inactivation but not structural mutation of p53 causes liver cancer. Nat. Genet. 1995, 9, 41-47. [CrossRef]

91. Anzola, M.; Cuevas, N.; López-Martínez, M.; Saiz, A.; Burgos, J.J.; Martínez de Pancorboa, M. p14 ${ }^{\text {ARF }}$ gene alterations in human hepatocellular carcinoma. Eur. J. Gastroenterol. Hepatol. 2004, 16, 19-26. [CrossRef]

92. Wade, M.; Li, Y.C.; Wahl, G.M. MDM2, MDMX and p53 in oncogenesis and cancer therapy. Nat. Rev. Cancer 2013, 13, 83-96. [CrossRef]

93. Feitelson, M.A.; Zhu, M.; Duan, L.X.; London, W.T. Hepatitis B x antigen and p53 are associated in vitro and in liver tissues from patients with primary hepatocellular carcinoma. Oncogene 1993, 8, 1109-1117. [PubMed]

94. Zhu, M.; London, W.T.; Duan, L.X.; Feitelson, M.A. The value of hepatitis B x antigen as a prognostic marker in the development of hepatocellular carcinoma. Int. J. Cancer 1993, 55, 571-576. [CrossRef] [PubMed]

95. Feitelson, M.A.; Ranganathan, P.N.; Clayton, M.M.; Zhang, S.M. Partial characterization of the woodchuck tumor suppressor, $\mathrm{p} 53$, and its interaction with woodchuck hepatitis virus $\mathrm{X}$ antigen in hepatocarcinogenesis. Oncogene 1997, 15, 327-336. [CrossRef] [PubMed]

96. Fukuyama, R.; Niculaita, R.; Ng, K.P.; Obusez, E.; Sanchez, J.; Kalady, M.; Aung, P.P.; Casey, G.; Sizemore, N. Mutated in colorectal cancer, a putative tumor suppressor for serrated colorectal cancer, selectively represses beta-catenin-dependent transcription. Oncogene 2008, 27, 6044-6055. [CrossRef] [PubMed]

97. Gao, X.; Qu, J.; Chang, X.; Lu, Y.; Bai, W.; Wang, H.; Xu, Z.; An, L.; Wang, C.; Zeng, Z.; et al. Hypomethylation of long interspersed nuclear element-1 promoter is associated with poor outcomes for curative resected hepatocellular carcinoma. Liver Int. 2014, 34, 136-146. [CrossRef] [PubMed]

98. Zhu, C.; Utsunomiya, T.; Ikemoto, T.; Yamada, S.; Morine, Y.; Imura, S.; Arakawa, Y.; Takasu, C.; Ishikawa, D.; Imoto, I.; et al. Hypomethylation of long interspersed nuclear element-1 (LINE-1) is associated with poor prognosis via activation of c-MET in hepatocellular carcinoma. Ann. Surg. Oncol. 2014, 21 (Suppl. 4), S729-S735. [CrossRef]

99. Zhang, C.; Fan, L.; Fan, T.; Wu, D.; Gao, L.; Ling, Y.; Zhu, J.; Li, R.; Wei, L. Decreased PADI4 mRNA association with global hypomethylation in hepatocellular carcinoma during HBV exposure. Cell Biochem. Biophys. 2013, 65, 187-195. [CrossRef]

100. Shitani, M.; Sasaki, S.; Akutsu, N.; Takagi, H.; Suzuki, H.; Nojima, M.; Yamamoto, H.; Tokino, T.; Hirata, K.; Imai, K.; et al. Genome-wide analysis of DNA methylation identifies novel cancer-related genes in hepatocellular carcinoma. Tumour Biol. 2012, 33, 1307-1317. [CrossRef]

101. Lee, W.Y.; Bachtiar, M.; Choo, C.C.S.; Lee, C.G. Comprehensive review of Hepatitis B Virus-associated hepatocellular carcinoma research through text mining and big data analytics. Biol. Rev. 2018. [CrossRef]

102. Lin, C.P.; Liu, C.R.; Lee, C.N.; Chan, T.S.; Liu, H.E. Targeting c-Myc as a novel approach for hepatocellular carcinoma. World J. Hepatol. 2010, 2, 16-20. [CrossRef]

103. Balsano, C.; Avantaggiati, M.L.; Natoli, G.; De Marzio, E.; Will, H.; Perricaudet, M.; Levrero, M. Full-length and truncated versions of the hepatitis B virus (HBV) X protein $(\mathrm{pX})$ transactivate the cmyc protooncogene at the transcriptional level. Biochem. Biophys. Res. Commun. 1991, 176, 985-992. [CrossRef]

104. Lee, S.; Kim, W.; Ko, C.; Ryu, W.S. Hepatitis B virus X protein enhances Myc stability by inhibiting $\mathrm{SCF}^{\mathrm{Skp} 2}$ ubiquitin E3 ligase-mediated Myc ubiquitination and contributes to oncogenesis. Oncogene 2016, 35, 1857-1867. [CrossRef] [PubMed]

105. Iizuka, N.; Tsunedomi, R.; Tamesa, T.; Okada, T.; Sakamoto, K.; Hamaguchi, T.; Yamada-Okabe, H.; Miyamoto, T.; Uchimura, S.; Hamamoto, Y.; et al. Involvement of c-myc-regulated genes in hepatocellular carcinoma related to genotype-C hepatitis B virus. J. Cancer Res. Clin. Oncol. 2006, 132, 473-481. [CrossRef] [PubMed]

106. Rockwood, L.D.; Felix, K.; Janz, S. Elevated presence of retrotransposons at sites of DNA double strand break repair in mouse models of metabolic oxidative stress and MYC-induced lymphoma. Mutat. Res. Mol. Mech. Mutagen. 2004, 548, 117-125. [CrossRef]

107. Gasior, S.L.; Preston, G.; Hedges, D.J.; Gilbert, N.; Moran, J.V.; Deininger, P.L. Characterization of pre-insertion loci of de novo L1 insertions. Gene 2007, 390, 190-198. [CrossRef]

108. Huang, Q.; Lin, B.; Liu, H.; Ma, X.; Mo, F.; Yu, W.; Li, L.; Li, H.; Tian, T.; Wu, D.; et al. RNA-seq analyses generate comprehensive transcriptomic landscape and reveal complex transcript patterns in hepatocellular carcinoma. PLoS ONE 2011, 6, e26168. [CrossRef] 
109. Boyault, S.; Rickman, D.S.; De Reyniès, A.; Balabaud, C.; Rebouissou, S.; Jeannot, E.; Hérault, A.; Saric, J.; Belghiti, J.; Franco, D.; et al. Transcriptome classification of HCC is related to gene alterations and to new therapeutic targets. Hepatology 2007, 45, 42-52. [CrossRef]

110. Gopal, R.; Selvarasu, K.; Pandian, P.P.; Ganesan, K. Integrative transcriptome analysis of liver cancer profiles identifies upstream regulators and clinical significance of ACSM3 gene expression. Cell. Oncol. 2017, 40, 219-233. [CrossRef]

111. Okabe, H.; Satoh, S.; Kato, T.; Kitahara, O.; Yanagawa, R.; Yamaoka, Y.; Tsunoda, T.; Furukawa, Y.; Nakamura, Y. Genome-wide Analysis of Gene Expression in Human Hepatocellular Carcinomas Using cDNA Microarray: Identification of Genes Involved in Viral Carcinogenesis and Tumor Progression. Cancer Res. 2001, 61, 2129-2137.

112. Kaufman, P.D. New Partners for HP1 in Transcriptional Gene Silencing. Mol. Cell 2011, 41, 1-2. [CrossRef]

113. Eissenberg, J.C.; Elgin, S.C. The HP1 protein family: Getting a grip on chromatin. Curr. Opin. Genet. Dev. 2000, 10, 204-210. [CrossRef]

114. Yang, Y.F.; Pan, Y.H.; Tian, Q.H.; Wu, D.C.; Su, S.G. CBX1 Indicates Poor Outcomes and Exerts Oncogenic Activity in Hepatocellular Carcinoma. Transl. Oncol. 2018, 11, 1110-1118. [CrossRef] [PubMed]

115. Vogel, M.J.; Guelen, L.; de Wit, E.; Hupkes, D.P.; Loden, M.; Talhout, W.; Feenstra, M.; Abbas, B.; Classen, A.K.; van Steensel, B. Human heterochromatin proteins form large domains containing KRAB-ZNF genes. Genome Res. 2006, 16, 1493-1504. [CrossRef] [PubMed]

116. Tomonaga, T.; Nagao, K.; Kawasaki, Y.; Furuya, K.; Murakami, A.; Morishita, J.; Yuasa, T.; Sutani, T.; Kearsey, S.E.; Uhlmann, F.; et al. Characterization of fission yeast cohesin: Essential anaphase proteolysis of Rad21 phosphorylated in the S phase. Genes Dev. 2000, 14, 2757-2770. [CrossRef] [PubMed]

117. Barber, T.D.; McManus, K.; Yuen, K.W.Y.; Reis, M.; Parmigiani, G.; Shen, D.; Barrett, I.; Nouhi, Y.; Spencer, F.; Markowitz, S.; et al. Chromatid cohesion defects may underlie chromosome instability in human colorectal cancers. Proc. Natl. Acad. Sci. USA 2008, 105, 3443-3448. [CrossRef] [PubMed]

118. Xu, H.; Tomaszewski, J.M.; McKay, M.J. Can corruption of chromosome cohesion create a conduit to cancer? Nat. Rev. Cancer 2011, 11, 199-210. [CrossRef] [PubMed]

119. Deb, S.; Xu, H.; Tuynman, J.; George, J.; Yan, Y.; Li, J.; Ward, R.L.; Mortensen, N.; Hawkins, N.J.; McKay, M.J.; et al. RAD21 cohesin overexpression is a prognostic and predictive marker exacerbating poor prognosis in KRAS mutant colorectal carcinomas. Br. J. Cancer 2014, 110, 1606-1613. [CrossRef] [PubMed]

120. Xu, H.; Yan, Y.; Deb, S.; Rangasamy, D.; Germann, M.; Malaterre, J.; Eder, N.C.; Ward, R.L.; Hawkins, N.J.; Tothill, R.W.; et al. Cohesin Rad21 mediates loss of heterozygosity and is upregulated via Wnt promoting transcriptional dysregulation in gastrointestinal tumors. Cell Rep. 2014, 9, 1781-1797. [CrossRef] [PubMed]

121. Lo, A.W.; Craig, J.M.; Saffery, R.; Kalitsis, P.; Irvine, D.V.; Earle, E.; Magliano, D.J.; Choo, K.H. A 330 kb CENP-A binding domain and altered replication timing at a human neocentromere. EMBO J. 2001, 20, 2087-2096. [CrossRef]

122. Amor, D.J.; Choo, K.H.A. Neocentromeres: Role in Human Disease, Evolution, and Centromere Study. Am. J. Hum. Genet. 2002, 71, 695-714. [CrossRef]

123. Chueh, A.C.; Northrop, E.L.; Brettingham-Moore, K.H.; Choo, K.H.A.; Wong, L.H. LINE Retrotransposon RNA Is an Essential Structural and Functional Epigenetic Component of a Core Neocentromeric Chromatin. PLoS Genet. 2009, 5, e1000354. [CrossRef]

124. Ding, D.; Lou, X.; Hua, D.; Yu, W.; Li, L.; Wang, J.; Gao, F.; Zhao, N.; Ren, G.; Li, L.; et al. Recurrent targeted genes of hepatitis $\mathrm{B}$ virus in the liver cancer genomes identified by a next-generation sequencing-based approach. PLoS Genet. 2012, 8, e1003065. [CrossRef] [PubMed]

125. Pinyol, R.; Tovar, V.; Llovet, J.M. TERT promoter mutations: Gatekeeper and driver of hepatocellular carcinoma. J. Hepatol. 2014, 61, 685-687. [CrossRef]

126. Huang, F.W.; Hodis, E.; Xu, M.J.; Kryukov, G.V.; Chin, L.; Garraway, L.A. Highly Recurrent TERT Promoter Mutations in Human Melanoma. Science 2013, 339, 957-959. [CrossRef] [PubMed]

127. Killela, P.J.; Reitman, Z.J.; Jiao, Y.; Bettegowda, C.; Agrawal, N.; Diaz, L.A.; Friedman, A.H.; Friedman, H.; Gallia, G.L.; Giovanella, B.C.; et al. TERT promoter mutations occur frequently in gliomas and a subset of tumors derived from cells with low rates of self-renewal. Proc. Natl. Acad. Sci. USA 2013, 110, 6021-6026. [CrossRef] 
128. Nault, J.C.; Calderaro, J.; Di Tommaso, L.; Balabaud, C.; Zafrani, E.S.; Bioulac-Sage, P.; Roncalli, M.; Zucman-Rossi, J. Telomerase reverse transcriptase promoter mutation is an early somatic genetic alteration in the transformation of premalignant nodules in hepatocellular carcinoma on cirrhosis. Hepatology 2014, 60, 1983-1992. [CrossRef]

129. Yang, X.; Guo, X.; Chen, Y.; Chen, G.; Ma, Y.; Huang, K.; Zhang, Y.; Zhao, Q.; Winkler, C.A.; An, P.; et al. Telomerase reverse transcriptase promoter mutations in hepatitis B virus-associated hepatocellular carcinoma. Oncotarget 2016, 7, 27838-27847. [CrossRef]

130. Li, W.; Zeng, X.; Lee, N.P.; Liu, X.; Chen, S.; Guo, B.; Yi, S.; Zhuang, X.; Chen, F.; Wang, G.; et al. HIVID: An efficient method to detect HBV integration using low coverage sequencing. Genomics 2013, 102, 338-344. [CrossRef]

131. Sung, W.K.; Zheng, H.; Li, S.; Chen, R.; Liu, X.; Li, Y.; Lee, N.P.; Lee, W.H.; Ariyaratne, P.N.; Tennakoon, C.; et al. Genome-wide survey of recurrent HBV integration in hepatocellular carcinoma. Nat. Genet. 2012, 44, 765-769. [CrossRef]

132. Zhao, L.H.; Liu, X.; Yan, H.X.; Li, W.Y.; Zeng, X.; Yang, Y.; Zhao, J.; Liu, S.P.; Zhuang, X.H.; Lin, C.; et al. Genomic and oncogenic preference of HBV integration in hepatocellular carcinoma. Nat. Commun. 2016, 7, 12992. [CrossRef]

133. Fujimoto, A.; Totoki, Y.; Abe, T.; Boroevich, K.A.; Hosoda, F.; Nguyen, H.H.; Aoki, M.; Hosono, N.; Kubo, M.; Miya, F; et al. Whole-genome sequencing of liver cancers identifies etiological influences on mutation patterns and recurrent mutations in chromatin regulators. Nat. Genet. 2012, 44, 760-764. [CrossRef] [PubMed]

134. Whittaker, S.; Marais, R.; Zhu, A.X. The role of signaling pathways in the development and treatment of hepatocellular carcinoma. Oncogene 2010, 29, 4989-5005. [CrossRef] [PubMed]

135. Liang, H.W.; Wang, N.; Wang, Y.; Wang, F.; Fu, Z.; Yan, X.; Zhu, H.; Diao, W.; Ding, Y.; Chen, X.; et al. Hepatitis B virus-human chimeric transcript HBx-LINE1 promotes hepatic injury via sequestering cellular microRNA-122. J. Hepatol. 2016, 64, 278-291. [CrossRef] [PubMed]

136. Leibold, D.M.; Swergold, G.D.; Singer, M.F.; Thayer, R.E.; Dombroski, B.A.; Fanning, T.G. Translation of LINE-1 DNA elements in vitro and in human cells. Proc. Natl. Acad. Sci. USA 1990, 87, 6990-6994. [CrossRef] [PubMed]

137. Horn, A.V.; Celic, I.; Dong, C.; Martirosyan, I.; Han, J.S. A conserved role for the ESCRT membrane budding complex in LINE retrotransposition. PLoS Genet. 2017, 13, e1006837. [CrossRef] [PubMed]

138. Harris, C.R.; Normart, R.; Yang, Q.; Stevenson, E.; Haffty, B.G.; Ganesan, S.; Cordon-Cardo, C.; Levine, A.J.; Tang, L.H. Association of Nuclear Localization of a Long Interspersed Nuclear Element-1 Protein in Breast Tumors with Poor Prognostic Outcomes. Genes Cancer 2010, 1, 115-124. [CrossRef]

139. Chen, Y.; Zeng, Q.; Liu, X.; Fu, J.; Zeng, Z.; Zhao, Z.; Liu, Z.; Bai, W.; Dong, Z.; Liu, H.; et al. LINE-1 ORF-1p enhances the transcription factor activity of pregnenolone $X$ receptor and promotes sorafenib resistance in hepatocellular carcinoma cells. Cancer Manag. Res. 2018, 10, 4421-4438. [CrossRef]

140. Nakayama, R.; Ueno, Y.; Ueda, K.; Honda, T. Latent infection with Kaposi's sarcoma-associated herpesvirus enhances retrotransposition of long interspersed element-1. Oncogene 2019. [CrossRef]

141. Nishikawa, Y.; Nakayama, R.; Obika, S.; Ohsaki, E.; Ueda, K.; Honda, T. Inhibition of LINE-1 Retrotransposition by Capsaicin. Int. J. Mol. Sci. 2018, 19, 3243. [CrossRef]

(C) 2019 by the authors. Licensee MDPI, Basel, Switzerland. This article is an open access article distributed under the terms and conditions of the Creative Commons Attribution (CC BY) license (http://creativecommons.org/licenses/by/4.0/). 